\title{
Description of Muscotabanus gen. nov. and Muscotabanus rafaeli sp. nov. (Diptera: Tabanidae: Diachlorini) from Amazon Basin, Brazil
}

\author{
Augusto Loureiro Henriques ${ }^{1 /+}$, Tiago Kütter Krolow ${ }^{2}$ \\ ${ }^{1}$ Coordenação de Pesquisas em Entomologia, Instituto Nacional de Pesquisas da Amazônia, Manaus, AM, Brasil \\ ${ }^{2}$ Coordenação de Ciências Biológicas, Universidade Federal do Tocantins, Porto Nacional, TO, Brasil
}

A new genus of Tabanidae mimetic of flies is described: Muscotabanus new genus, Muscotabanus rafaeli new species, based on 12 females collected in the state of Amazonas, Brazil. It is presented a discussion for separating the new genus from Diachlorini species which resemblance with sarcophagids flies. It is characterised by striped thorax, banded abdomen, long slender palpus subequal antenna length, labella predominantly membranous, except for a narrow sclerotised plate, basicosta bare, wing hyaline and stigma brown.

Key words: mimetic horseflies - new genus - tabanids - taxonomy

The tabanids are stout-bodied flies, commonly known as horse flies or deer flies. The family is allocated in suborder Brachycera Macquart, clade Orthorrhapha Brauer, and has 4,434 species distributed in 156 genera (Pape et al. 2011). Among tabanids, the Diachlorini has the highest richness in the Neotropical region, with 594 species of a total 1,205 valid species (Henriques et al. 2012). Some species, such as Eutabanus Kröber, Myiotabanus Lutz, Philipotabanus Fairchild and Stypommisa Enderlein, have specimens mimetic of Muscomorpha dipterous like Sarcophagidae and Muscidae.

Analysing the entomological collection of National Institute for Amazonian Research (INPA), it was found unidentified female specimens of Diachlorini rather similar to muscoids. They are being described as a new genus and species below.

\section{MATERIALS AND METHODS}

The material studied is deposited in the Collections of the INPA [Manaus, state of Amazonas (AM)], Museu Paraense Emílio Goeldi (MPEG) (Belém) and Museum of Zoology of the University of São Paulo (MZUSP) (São Paulo). Specimens were examined and digitally photographed through a stereomicroscope LEICA M205 C coupled with a LEICA DFC 295 camera and software for digital image processing Leica Application Suite LAS V3.6. The terminalia was drawn using a camera lucida coupled to optic microscope LEICA DM 1000.

Terminology follows Burger (2009) and Cumming and Wood (2009). Dissection follows Cumming (1992) protocol.

Financial support: CNPq (156156/2010-5), FAPEAM (1437/2007),

Gordon \& Betty Moore Foundation, WWF

+Corresponding author: loureiro@inpa.gov.br

Received 31 August 2012

Accepted 4 December 2012

\section{RESULTS}

Muscotabanus gen. nov. -

Type species Muscotabanus rafaeli sp. nov.

Eye bare, unicolored. Ocelli absent. Frons weakly divergent above. Frontal callus clavate (ridge-like) narrower than frons. Basal plate of flagellum with acute short dorsal projection, somewhat variable, but not as tooth or spine. Subcallus, clypeus and gena grey pruinescent. Palpus long and slender subequal to antenna length. Labella predominantly membranous, except for a narrow sclerotised plate. Basicosta bare. Wing hyaline, stigma brown. Venation normal, sometimes a little appendage in the fork of vein $\mathrm{R}_{4+5}$. Legs slender. Genital fork compact, with small acute internal projection in the central cavity.

Muscotabanus rafaeli $\mathrm{sp}$. nov.

(Figs 1-9)

Diagnosis - Body length $10.6 \mathrm{~mm}$, thorax black and white striped, muscoid appearance. Frons relatively wide, slightly divergent at apex, frontal callus clavate, ridge-like. Basal plate with dorsal raised angle, stylus longer than basal plate length. Wing hyaline, basicosta bare. Abdominal segments banded black haired basally, white haired and white pruinescence on hind margins.

Head: eyes red-brownish in life. Ocellar tubercle vestigial, ocelli absent, vertex black with small sclerotised area, black haired. Frons (Fig. 3) slightly convergent basally, white-brownish pruinose, yellowish dorsally, with black and white hairs; frontal index 5.0; divergence index 1.4; frontal callus blackish, clavate (ridge-like), narrower than frons (not touching the lower inner margin of the compound eyes) and extending until superior half of frons. Subcallus white pruinose. Clypeus and gena with white pruinescence and hairs. Palpus brown, white pruinescent, slender and elongated; first segment long and white hairs; second segment mainly white haired and some black at distal third. Theca brown, membranous; labella brown, mostly membranous (Fig. 5). Antenna (Fig. 4): scape and pedicel brown-orange with black pi- 
losity; basal plate brown with a dorsal raised projection, stylus brown to black with four annuli longer than basal plate length.

Thorax: scutum dorsally (Fig. 1) black pruinescent, covered with black and white hairs, except for two white paramedian longitudinal stripes and laterally from postpronotal lobe to postalar callus whitish and predominantly white haired, with few black hairs. Notopleural lobe (lateral view), whitish with many black hairs. Scutellum (dorsal view), bicoloured, anterior half black pruinescent and black haired, posterior margin white pruinescent black and white haired. Pleuron white pruinescent and pilosity, except for anepisternum black haired ventrally. Legs slender, coxae concolorous with pleuron. Trochanters, femora, tibiae and tarsi dark brown, black haired. Wing hyaline with dark brown veins; pterostigma brown; $\mathrm{R}_{4+5}$ with a small appendix at fork of (only in right wing in holotype).

Abdomen: all tergites and sternites black basally, white pruinescent and white haired at hind margins, except tergite 1 with white lateral pruinescence and pilosity (Figs 1,2).

Terminalia: hypogynium (sternite 8) and hypoginal valve (gonapophysis) fused, posterior margin with a small indentation (Fig. 6). Tergite 9 divided, smaller than tergite 10 , tapered at outer margin; tergite $10 \mathrm{di}-$ vided, subretangular, inner margin rounded; cercus with rounded apex; hypoproct half moon-like (Fig. 7). Genital fork with median notch in anterior margin; two tufts of strong bristles at apex; central cavity subtriangular with one spine-shaped internal process at each side (Fig. 8). Spermatheca elongate with rounded apex; caudal end of spermathecal ducts with cup-like expansion (Fig. 9).

\section{Male - Unknown.}

Variations (paratypes) - Body length 9.7-11.7 mm; short appendix at fork of $\mathrm{R}_{4+5}$ just in few specimens.

\section{Distribution - Brazil (AM).}

Type data and depository - Holotype: female: Brazil, Manaus, AM 010, Km 54 BI-2, 02 $45^{\circ} 33^{\prime \prime}$ S 59 51'03"W, 1-10.vi.1998, Suspensa/clareira 2 [suspendable Malaise trap/open Field 2], ig.[arapé], RLM Ferreira, AL Henriques \& JF Vidal leg. (INPA). Paratypes: Brazil, Manaus, PDBFF/WWF, Proj. Bert Klein, ii.1985, Malaise [trap], (no data about collector) (female INPA); idem, v.1985 (female INPA); idem, viii.1984, ?"Stenotabanus", Philipotabanus (Mimotabanus) sp. nr. porteri det. JE Chainey, 1998, (no data about collector) (female INPA); Manaus, AM 010, Km 54 BI-2, 12-23.vi.1997, Malaise/clareira [Malaise trap/open field], RLM Ferreira, AL Henriques \& JF Vidal leg. (female INPA); idem, 21-31.vii.1997, Suspensa/clareira [suspendable Malaise trap/open field] (female MPEG, female INPA); Manaus, Reserva Ducke, 22.viii.1978, Malaise trap, J Arias \& N Penny leg., Phaeotabanus or Myiotabanus, "Stenotabanus" sp. nov. det. Fairchild, 1981, Stypommisa sp. det. JE Chainey, 1997 (female INPA); Manaus, Sítio Vida Tropical, Malaise [trap], mata [forest], 12.vi.1997, (no data about collector) (female
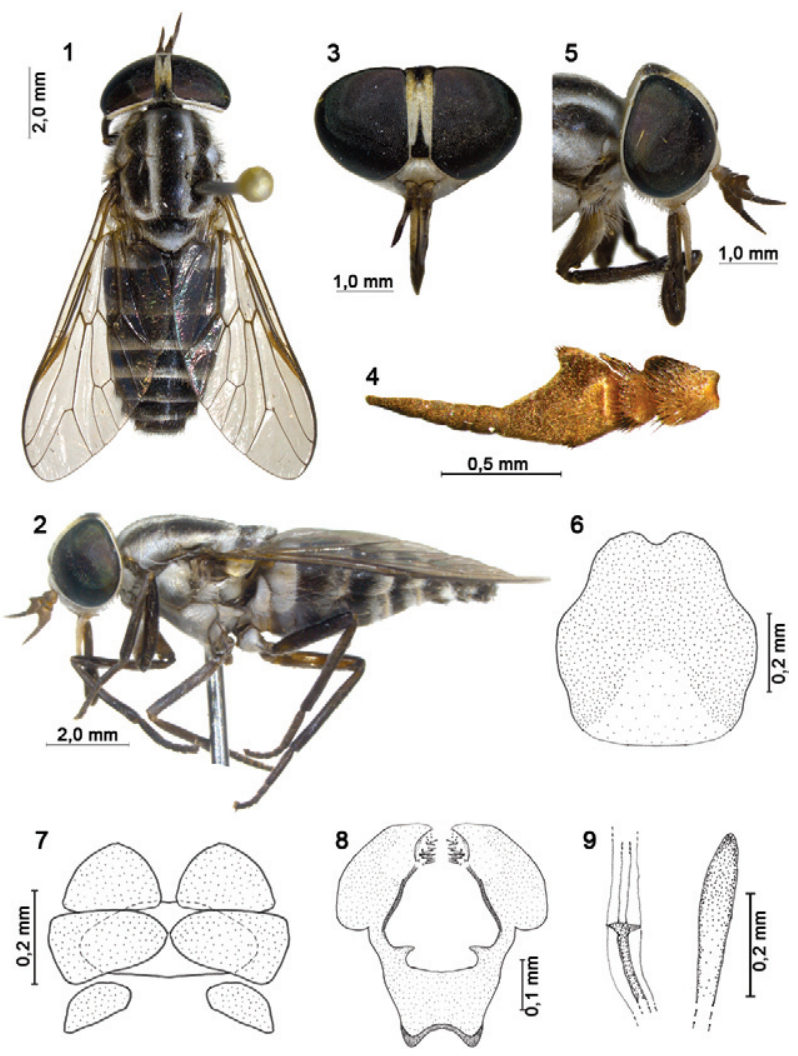

1-5: Muscotabanus rafaeli gen. n, sp. nov. Holotype female. 1: habitus, dorsal view; 2: habitus, lateral view; 3: head, frontal view; 4: antenna; 5: head, lateral view; 6-9: paratype female; 6 : hypogynium and hypoginal valve, ventral view (setae not represented); 7: tergites 9 and 10, cercus and hipoproct, dorsal view (setae not represented); 8: genital fork, dorsal view; 9: spermatheca and caudal end of spermathecal duct.

INPA); Barcelos, em campina [open field], $0^{\circ} 28^{\prime} 38^{\prime \prime} \mathrm{N}$ $63^{\circ} 28^{\prime} 18^{\prime}$ 'W, vii-viii.2007, arm. suspensa lâmina d'água de igarapé [suspendable Malaise trap over the water surface in igarapé], AS Filho \& T Krolow leg. (female MZUSP); Barcelos, Serrinha, $0^{\circ} 25^{\prime} 05^{\prime \prime} \mathrm{N} 63^{\circ} 23^{\prime} 05^{\prime \prime} \mathrm{W}$, vii-viii.2007, arm. suspensa lâmina d'água de lago [suspendable Malaise trap over the water surface in lake], olhos unicoloridos vermelho-amarronzado [eyes without pattern, red-brownish], AS Filho \& T Krolow leg. (female INPA); Rio Nhamundá, ig. Areias, $01^{\circ} 35^{\prime} 11^{\prime \prime} \mathrm{S}$ 57³7'32”W, 17-20.v.2008, arm. suspensa lâmina d'água [suspendable Malaise trap over the water surface], JA Rafael leg. (female INPA).

Etimology - Generic name derives from Latim: mus$c a+$ tabanus; specific name is a tribute to the entomologist José Albertino Rafael, from INPA.

\section{DISCUSSION}

Some specimens from INPA's collection contain genus identification labels with questions as "Stenotabanus?". GB Fairchild (1981, on a letter to JA RafaelINPA) did the following comments about this species: "This is a new species similar to St. tantulas Hine from 


\section{TABLE}

Similarities and differences between Muscotabanus gen. nov. and Catachlorops, Eutabanus, Myiotabanus, Philipotabanus (Mimotabanus), Stenotabanus and Stypommisa

\begin{tabular}{|c|c|c|}
\hline & Similarities & Differences \\
\hline Catachlorops & $\begin{array}{l}\text { Eyes unicolourous, slender legs, } \\
\text { clavate frontal callus (ridge-like). }\end{array}$ & $\begin{array}{l}\text { Labella predominantly sclerotised, } \\
\text { long-spined antenna, pictured wings. }\end{array}$ \\
\hline Eutabanus & $\begin{array}{l}\text { Mimetic aspect with flies, } \\
\text { eyes unicolourous. }\end{array}$ & $\begin{array}{l}\text { Conical and protuberant notopleuron, } \\
\text { inflated fore tibiae, flattened hind tibiae. }\end{array}$ \\
\hline Myiotabanus & $\begin{array}{l}\text { Mimetic aspect with flies, } \\
\text { eyes unicolourous, long proboscis. }\end{array}$ & $\begin{array}{l}\text { Short and inflated palpi, } \\
\text { acutely pointed female abdomen. }\end{array}$ \\
\hline Philipotabanus (Mimotabanus) porteri & $\begin{array}{l}\text { Mimetic aspect with flies, } \\
\text { eyes unicolourous reddish. }\end{array}$ & $\begin{array}{l}\text { Pictured wings below stigma, } \\
\text { basicosta with setae, vestiges of ocelli present. }\end{array}$ \\
\hline Stenotabanus & $\begin{array}{l}\text { Bare eyes, predominantly } \\
\text { membranous labela. }\end{array}$ & $\begin{array}{l}\text { Eyes with at least two transverse bands in } \\
\text { life, callus not ridge-like generally as wide as frons. }\end{array}$ \\
\hline Stypommisa & $\begin{array}{l}\text { Few species mimetics of flies, } \\
\text { eyes generally unicolourous. }\end{array}$ & $\begin{array}{l}\text { Short proboscis, membranous labela, } \\
\text { basicosta generally with setae. }\end{array}$ \\
\hline
\end{tabular}

it was used Fairchild (1969) for characters presented here.

Br. Guiana, but smaller, with narrower and slightly different frons etc. I have another species from Rio de Janeiro which seems obviously related, but which lacks the thoracic stripes of your species (INPA). All three specimens are quite similar and quite different from most Stenotabanus. In some ways they are like Philipotabanus, but I believe represent a distinct genus of unknown affinity. None are similar to Myiotabanus, which has a peculiar frons, very short stout palpi and very long proboscis".

St. tantulas refers to Stypommisa tantula (Hine, 1920) treated as invalid species by Fairchild and Wilkerson (1986) and removed from Catalog of the Tabanidae of Fairchild and Burger (1994) without any justification, but it was again included in Stypommisa by Coscarón and Papavero (2009). In 1996 we sent two female specimens to Dr JE Chainey (The Natural History Museum, London), who at the time was making a revision of South American Stenotabanus. He very helpfully identified the material as: "Philipotabanus (Mimotabanus) sp. near porteri" and "Stypommisa sp." respectively. He did not included in Stenotabanus, demonstrating the degree of uncertainty in identifying the genus of this taxon.

Following Fairchild's (1969) genera key, Muscotabanus gen. nov. run to couplet 19 (p. 232) of Catachlorops Lutz. It clearly does not belong to this genus. Similarities and differences with other genera in appearance are presented below (Table).

\section{REFERENCES}

Burger JF 2009. Tabanidae (horse flies, deer flies, tabanos). In BV Brown, A Borkent, JM Cumming, DM Wood, NE Woodley, M Zumbado, Manual of Central American Diptera, Vol. 1, NRC Research Press, Otawa, p. 495-507.

Coscarón S, Papavero N 2009. Catalogue of neotropical Diptera. Tabanidae. Neotropical Diptera 16: 1-199.

Cumming JM 1992. Lactic acid as an agent for macerating Diptera specimens. Fly Times 8: 7.

Cumming JM, Wood DM 2009. Adult morphology and terminology. In BV Brown, A Borkent, JM Cumming, DM Wood, NE Woodley, M Zumbado, Manual of Central American Diptera, Vol. 1, NRC Research Press, Otawa, p. 9-50.

Fairchild GB 1969. Notes on neotropical Tabanidae XII. Classification and distribution with keys to genera and subgenera. Arq Zool 17: 199-255.

Fairchild GB, Burger JF 1994. A catalog of the Tabanidae (Diptera) of the Americas, south of the United States. Mem Amer Ent Inst 55: 1-249.

Fairchild GB, Wilkerson RC 1986. A review of the neotropical genus Stypommisa (Diptera: Tabanidae). Contrib Amer Ent Inst 22: 1-61.

Henriques AL, Krolow TK, Rafael JA 2012. Corrections and additions to Catalogue of Neotropical Diptera (Tabanidae) of Coscarón \& Papavero (2009). Rev Bras Entomol 56: 277-280.

Pape T, Blagoderov V, Mostovski MB 2011. Order Diptera Linnaeus, 1758. In Z-Q Zhang, Animal biodiversity: an outline of higherlevel classification and survey of taxonomic richness. Zootaxa 3148: 222-229. 